\section{EDWARD W. ARIAN}

Dr. Edward W. Arian, a renaissance man. He navigated two very successful careers, one as a world class professional musician and one as a political scientist. In addition to his family, which was most important to him, these were the other important components of his life.

As a young man born in Cleveland, Ohio, music became an important part of his early years. He graduated from Glenville High School in 1939 and then served in the Navy during World War II as a musician. He went on to earn a diploma from the Curtis Institute of Music in 1944. Later, he received his bachelor's degree in 1960 from Combs College of Music in Philadelphia. He was a member of the world-renowned Philadelphia Orchestra (1947-67), with Eugene Ormandy, for which he eventually became assistant principal bass. Prior to joining the Philadelphia Orchestra, he was a member of the Denver Symphony (1945-46) and the San Francisco Symphony (1946-47).

As a member of the orchestra, he served as a labor negotiator for Local \#77 of the American Federation of Musicians, in 1966. In that role, he helped to lead a successful eight-week strike that resulted in the musicians getting their first guaranteed 5 2-week salary and better wages.

After this experience, Arian came to a new understanding of himself. "While music was always an important part of his life," his wife Yvette said, "he grew to the point where he wanted more. His deep interest in politics led him in 1967 to go to Bryn Mawr College, where he received his Ph.D. in political science in 1969." His time with the orchestra provided the basis for him to write his dissertation on his experiences there. This later evolved into his classic book Bach, Beethoven, and Bureaucracy: The Case of the Philadelphia Orchestra (University of Alabama Press, 1971).

For many, Arian was often recognized as the man who had played in the Philadelphia Orchestra and later entered academia. His wife Yvette said, "While his tenure at the orchestra was for 20 years, his second career was then launched where he was a professor at Drexel University for 29 years. As a scholar, he was able to do many more things that he was really interested in through his academic life."
After a few short years, he was chosen to become the head of the department of history and politics in 1976. His levelheadedness and skill at administration were evident to all. However, in addition to being a skilled administrator and teacher, he had the remarkable ability to be a creator. He is perhaps best known for his work creating the Drexel University arts administration program in 1973, for which he served as the program's founder. Drexel was one of the first arts administration programs in the nation. "Dr. Arian was a visionary who understood the need for good management in the cultural community," said Cecilia Fitzgibbon, arts administration program director. "His understanding of the public role of the arts and the impact of class on cultural participation influenced a generation of arts leaders. Dr. Arian was an important figure in the development of arts administration as a field of study, and he will be missed by many."

His growth did not stop at Drexel. He was also the founder and director of the graduate program in environmental planning and management, as well as the undergraduate program in public administration. He was responsible for utilizing student internships through grant funding to aid local governments in technical assistance.

Outside of Drexel, after serving on the Pennsylvania Council of the Arts for six years, Dr. Arian was appointed by then governor Milton J. Shapp, in 1979, to become the chairman of the council. His experiences led to a second book, Unfulfilled Promise: Public Subsidy of the Arts in America (Temple University Press, 1989). This work addressed important issues related to the National Endowment of the Arts and the state arts agencies. Peter Bachrach wrote, "This important book makes a significant contribution to political science, both in the fields of American government and political theory. Further, it may well shake up the cultural establishment by becoming a catalyst for democratic reform in this area."

In 1981, Dr. Arian became professor emeritus at Drexel University. In addition, Dr. Arian served as a visiting professor in arts administration at the University of Pennsylvania's Wharton School and at the
University of California-Los Angeles. He also served as an arts management consultant to organizations such as the San Diego Symphony Orchestra and the Southwest Florida Orchestra. He served as the chairman of the Curtis Institute's Alumni Affairs Council from 1995 to 2001 and then received the institution's Alumni Award in 2002.

Yvette said, "He never gave up the music, but he wanted more." While Ed continued to occasionally step in at the Philadelphia Orchestra when they needed his talents as a bass player, he also taught at what is now the Boyer School of Music at Temple University from 1960 to 1974.

At his memorial service, one of his two daughters explained to the attendees that whenever they would travel as family, there were always three in the backseat-his two daughters and the bass violin. Family was always important to him. In 2001, he decided that he would not be playing his instrument anymore when he moved into a retirement community. He found a place for his double bass violin with the renowned first-chair bass player in the Houston Symphony. He wanted to be sure that it went to a good home. But he never gave up his interest in politics. Even at the retirement community where he resided, he continued to be actively engaged in politics. He offered a very well-attended class in "News and Views."

Ed Arian passed away on February 12, 2010, at the age of 88 , of congestive heart failure. His legacy continues through the work he created, the students and faculty he touched, and the family he loved. Dr. Arian is survived by his wife of 67 years, Yvette, daughters Anne-Lesley and Carol, and his five grandchildren.

\section{William L. Rosenberg Drexel University}

\section{MALCOLM EDWIN JEWELL}

Malcolm "Mac" Jewell was a mainstay of the Political Science Department at the University of Kentucky (UK) for 36 years. For that same period and even longer, he was one of the profession's leading researchers in explaining legislative behavior (particularly in the states) and how state 